\title{
Hypermutation in mantle cell lymphoma does not indicate a clinical or biological subentity
}

\author{
Margit Schraders ${ }^{1,5}$, Sabine Oeschger ${ }^{2,5}$, Philip M Kluin ${ }^{3}$, Konnie Hebeda ${ }^{1}$, Ed Schuuring ${ }^{3}$, \\ Patricia JTA Groenen ${ }^{1}$, Martin-Leo Hansmann ${ }^{4}$ and Johan HJM van Krieken ${ }^{1}$ \\ ${ }^{1}$ Department of Pathology, Radboud University Nijmegen Medical Centre, Nijmegen, the Netherlands; \\ ${ }^{2}$ Department of Pathology, University Hospital Giessen, Giessen, Germany; ${ }^{3}$ Department of Pathology, \\ University Medical Center Groningen, University of Groningen, Groningen, the Netherlands and ${ }^{4}$ Department \\ of Pathology, University Hospital Frankfurt, Frankfurt, Germany
}

\begin{abstract}
Mantle cell lymphoma is a prime example of a well-defined entity based on morphology, phenotype, genetics and also clinical features. Although most patients have an adverse clinical course, some have a better survival than others. The most consistently reported adverse prognostic parameter is a high mitotic rate. Recently, it has been shown that hypermutation in the immunoglobulin heavy-chain gene occurs in a subset of mantle cell lymphomas. It is, however, unclear whether the mutational status is stable over time within a given case, whether hypermutation might be influenced by therapy and how it is related to other relevant biological features of mantle cell lymphoma. In this study, we analyzed 23 typical mantle cell lymphoma cases with respect to mutational status and compared the results with clinicopathological and genetic data to determine whether the presence of mutation indicates a subentity with clinical or pathological relevance. We found somatic hypermutation in $26 \%$ of our cases and, interestingly, one case showed ongoing somatic hypermutation. In tumor cells of both mutated and unmutated cases, we found a preferential usage of $V_{H} 3-21(23 \%)$ and $V_{H} 4-34$ $(19 \%)$. No significant correlations were found between mutation status and the other morphological and genetic features analyzed. In conclusion, our results provide additional evidence that mutation status in mantle cell lymphoma is better interpreted as a feature within the spectrum of disease that seems to have little clinical or pathological relevance.
\end{abstract}

Modern Pathology (2009) 22, 416-425; doi:10.1038/modpathol.2008.199; published online 9 January 2009

Keywords: mantle cell lymphoma; somatic hypermutation; $V_{H}$ gene usage

Malignant lymphomas are presently considered as a series of clinicopathological entities. Each entity is defined on histological, phenotypic, genetic and, to a lesser extent, clinical features. Within a given entity, there is often a spectrum of morphology, phenotype, genetics and also clinical features. These latter aspects can be used as prognostic factor or alternatively to define a subentity. Mantle cell lymphoma is a prime example of a very well defined entity with several specific prognostic factors. The tumor is characterized by the $\mathrm{t}(11 ; 14)$ translocation, which places the $B C L 1$ locus under the influence of the immunoglobulin heavy-chain gene enhancer, resulting in overexpression of cyclin D1. ${ }^{1}$ Mantle

Correspondence: Professor Dr JHJM van Krieken, Department of Pathology, Radboud University Nijmegen Medical Centre, Geert Grooteplein 24, Nijmegen 6500 HB, the Netherlands.

E-mail: j.vankrieken@pathol.umcn.nl

${ }^{5}$ These authors contributed equally to this work.

Received 22 August 2008; revised and accepted 19 November 2008; published online 9 January 2009 cell lymphoma has rather specific morphology with monomorphic small- to medium-sized lymphoid tumor cells with a nodular, diffuse or mantle zone growth pattern; however, about $20 \%$ are of the blastoid variant. ${ }^{2}$ The median survival for patients with mantle cell lymphoma is $3-5$ years; the vast majority of patients cannot be cured. The most consistently reported adverse histopathological prognostic parameter is a high mitotic rate. ${ }^{3}$ Other adverse prognostic factors are blastoid morphology $^{2,4}$ and the presence of p53 mutation accompanied by $17 p$ deletion. ${ }^{5-7}$

Recently, it has been shown that hypermutation in the immunoglobulin heavy-chain gene occurs in a subset of mantle cell lymphomas, but the biological relevance is unclear. $^{8-12}$ In analogy with the situation in chronic lymphocytic leukemia/small lymphocytic lymphoma, it was suggested that mutated cases might be considered as a relevant subentity with different biological features and clinical behavior. ${ }^{13-15}$ It is, however, at present unclear whether the mutational status is stable over time within a 
given case, whether it might be influenced by therapy and how it is related to other relevant biological features of mantle cell lymphoma, such as genetic imbalances, breakpoints in the BCL1/CCND1 locus and proliferative and apoptotic rate.

In this study, we analyzed a series of typical mantle cell lymphomas with respect to mutational status and compared the results with clinicopathological, morphological and genetic data to determine whether the presence of mutation indicates a subentity with clinical or pathological relevance.

\section{Materials and methods}

\section{Case Selection}

A total of 27 specimens from 23 patients were selected from the tissue banks of the departments of pathology of University Medical Centre Nijmegen, University Medical Centre Groningen, Rijnstate Hospital Arnhem and PATHAN, Rotterdam, the Netherlands. All cases were stained for cyclinD1 and CD5 and were reviewed by four experienced pathologists at a multiheaded microscope. The only inclusion criterion was the diagnosis of classical mantle cell lymphoma and the availability of frozen tissue. Morphological features were assessed including (vaguely) nodular growth, mantle zone growth and marginal zone or monocytoid differentiation of the tumor cells. Mitotic figures were counted per 15 high power fields (hpf). From two patients, serial biopsies were available, MC50, 51, 52 and 53 plus MC63 and 66, which were divided over a period of 7 years and 1 year, respectively.

\section{Immunohistochemistry}

From all cases, 4- $\mu \mathrm{m}$-thick tissue sections of paraffin-embedded tissue were stained for CD20, CD5 (both Dako, Denmark) and cyclinD1 (Neomarkers) for diagnostic purpose. The cases were also stained for Ki-67 (mib1, DAKO, Denmark). Immunohistochemistry was performed using a standard two-step immunoperoxidase method, including development with the ABC-method (DAKO, Denmark) and DAB as chromogen. Furthermore, immunofluorescence was used for the assessment of immunoglobulin heavy and light chains. Ki-67-positive tumor cells were counted by using an automated procedure as described previously. ${ }^{16}$

\section{DNA Extraction from Tissue Sections}

For DNA isolation, QIAamp DNA Mini Kit (Qiagen) was used. Tissue sections with thickness of 20-30 $\mu \mathrm{m}$ were digested overnight with $40 \mu \mathrm{l}$ proteinase $\mathrm{K}$ solution $(20 \mathrm{mg} / \mathrm{ml}$ ) and $360 \mu \mathrm{l}$ ATL (QIAmp Tissue Lysis) buffer at $55^{\circ} \mathrm{C}$. The DNA was precipitated by the addition of $6 \mathrm{M} \mathrm{NaCl}$ and dissolved in $\mathrm{H}_{2} \mathrm{O}$ at a concentration of $100 \mu \mathrm{g} / \mathrm{ml}$. A quantity of
$100 \mathrm{ng}$ of this extracted DNA was used in each amplification reaction.

\section{PCR and Sequence Analysis}

The clonal $\mathrm{V}_{\mathrm{H}}$ gene rearrangements of the mantle cell lymphoma cases were identified by PCR using family-specific $\mathrm{V}_{\mathrm{H}}$ framework region (FR) I primers together with a $\mathrm{J}_{\mathrm{H}}$ gene consensus primer according to the BIOMED-2 protocol. ${ }^{17}$ PCR products were purified and sequence analysis was performed on an automatic sequencing platform (ABI 3730, Applied Biosystems). Sequences were analyzed using the IMGT database (http://imgt.cines.fr:8104/). The $\mathrm{V}_{\mathrm{H}}$ gene sequences were considered mutated when the sequences showed less than $98 \%$ homology with the corresponding germline sequence.

For light-chain gene rearrangement identification, $100 \mathrm{ng}$ of genomic DNA was used in a $50 \mu \mathrm{l}$ PCR mixture with the family specific kappa and lambda primers according to the BIOMED-2 protocol.

\section{Southern Blot Analysis}

15-20 $\mu \mathrm{g}$ of genomic DNA was digested with Bg/II and HindIII (Life Technologies, Rockville, MD, USA) and separated in $0.7 \%$ agarose gels. The DNA was transferred by vacuum blotting to Nytran-13N nylon membranes (Schleicher and Schuell, Dassel, Germany), which were subsequently hybridized with ${ }^{32}$ P-labeled probes. For the determination of the IGK gene configuration probes specific for Jk (IGKJ5), Ck $(I G K C)$ and $\mathrm{K}_{\mathrm{de}}(I G K D E)$ (DAKO Corporation, Carpinteria, CA, USA) were used. ${ }^{18}$ To examine the IGL locus, the IGLC1D and IGLJ2 probes were used..$^{19}$

\section{The Detection of BCL1/11q13 Breakpoints}

For the detection of breakpoints in the 800-kb BCL1/ 11 113 region around $C C N D 1$, a previously designed interphase FISH segregation assay was performed using a probe set containing cosmids cos6.7/cCl-1144 in combination with cos6.31/cosH1.5. ${ }^{20}$ To identify breakpoints immediately $3^{\prime}$ of the CCND1 gene (breakpoint cluster 4), cosmid cos6.22/CCND1 in combination with cos6.31/cosH1.5 were used. ${ }^{21}$ To map breaks within the 85-bp BCL1/MTC-region (cluster 2), we performed the $\mathrm{t}(11 ; 14)$-specific BCL1/ JH-PCR as described previously. ${ }^{17}$ To map breaks in the 120-kb region between MTC and CCND1 (but outside the 4000-bp MTC), an additonal segregation FISH with P1 clone 9107/11q13 and cos6.22/CCND1 was used (cluster 3). ${ }^{22}$ Breaks detected within the 800-kb BCL1-region but outside clusters 2-4 are located centromeric of the MTC (cluster 1). Probes were labeled by Kreatech's ULS nonenzymatic labeling method (Kreatech Diagnostics, The Netherlands) with biotin-16-aUTP or digoxygenin-11-dUTP (Roche, Basel, Switzerland). Hybridization, 
Table 1 Morphological and immunohistochemical features of mantle cell lymphoma

\begin{tabular}{|c|c|c|c|c|c|}
\hline Sample & Age/sex & Biopsy & Growth pattern & Morphological variants & Immunophenotype \\
\hline MC01 & ND & Tonsil & Nodular & & CD5- cyclind1+ \\
\hline MC07 & $78 / \mathrm{M}$ & Lymph node & Nodular & & CD5- cyclinD1+ \\
\hline MC08 & $69 / F$ & Lymph node & Mantle zone, nodular & Monocytoid & CD5+ cyclinD1+ \\
\hline MC17 & $61 / \mathrm{M}$ & Lymph node & Nodular & Pleomorphic & CD5+ cyclinD1+ \\
\hline MC29 & $51 / \mathrm{M}$ & Lymph node & Nodular & & CD5+ cyclinD1+ \\
\hline MC31 & $55 / \mathrm{M}$ & Lymph node & Nodular & Monocytoid & CD5+ cyclinD1+ \\
\hline MC36 & $67 / \mathrm{M}$ & Lymph node & Nodular & & CD5- cyclinD1+ \\
\hline MC42 & $56 / \mathrm{F}$ & Lymph node & Diffuse & & CD5+ cyclinD1+ \\
\hline MC43 & $49 / \mathrm{M}$ & Lymph node & Nodular & & CD5- cyclinD1+ \\
\hline MC44 & $59 / \mathrm{M}$ & Lymph node & Nodular & & CD5+ cyclinD1+ \\
\hline MC45 & $53 / \mathrm{M}$ & Lymph node & Diffuse & & CD5+ cyclinD1+ \\
\hline MC47 & $67 / \mathrm{M}$ & Lymph node & Mantle zone, nodular & & CD5+ cyclinD1+ \\
\hline MC48 & $71 / \mathrm{M}$ & Lymph node & Nodular & Monocytoid & CD5+ cyclinD1+ \\
\hline $\mathrm{MC}^{\mathrm{a}} 0^{\mathrm{a}}$ & $54 / \mathrm{F}$ & Lymph node & Nodular & & CD5+ cyclinD1+ \\
\hline MC51 $^{\mathrm{a}}$ & $56 / \mathrm{F}$ & Lymph node & Nodular & & CD5+ cyclinD1+ \\
\hline MC52 ${ }^{\mathrm{a}}$ & $58 / \mathrm{F}$ & Lymph node & Nodular & & CD5+ cyclinD1+ \\
\hline MC53 $^{\mathrm{a}}$ & $61 / \mathrm{F}$ & Lymph node & Nodular & & CD5+ cyclinD1+ \\
\hline MC56 & $79 / F$ & Lymph node & Diffuse & & CD5+ cyclinD1+ \\
\hline MC57 & $62 / \mathrm{F}$ & Lymph node & Nodular & & CD5+ cyclinD1+ \\
\hline MC58 & $82 / \mathrm{M}$ & Lymph node & Nodular & & CD5+ cyclinD1+ \\
\hline MC59 & $77 / \mathrm{M}$ & Lymph node & Nodular & & CD5+ cyclinD1+ \\
\hline MC61 & $73 / \mathrm{M}$ & Lymph node & Nodular & & CD5+ cyclinD1+ \\
\hline MC62 & $85 / F$ & Lymph node & Nodular & & CD5+ cyclinD1+ \\
\hline $\mathrm{MC}^{\mathrm{b}}{ }^{\mathrm{b}}$ & $43 / \mathrm{M}$ & Lymph node & Nodular & & CD5+ cyclinD1+ \\
\hline MC65 & $46 / \mathrm{M}$ & Lymph node & Nodular & Monocytoid & CD5+ cyclinD1+ \\
\hline MC66 $^{\mathrm{b}}$ & $43 / \mathrm{M}$ & Adenoid & Nodular & & CD5+ cyclinD1+ \\
\hline MC67 & $68 / \mathrm{M}$ & Spleen & Nodular & & CD5+ cyclinD1+ \\
\hline
\end{tabular}

ND, no data available.

${ }^{\mathrm{a}}$ Same patient.

${ }^{\mathrm{b}}$ Same patient.

immunodetection and fluorescence microscopy were performed as described previously. ${ }^{20}$ Breakpoints are defined by the segregation of one or both probe sets and the presence of single red and/or single green hybridization signals in tissue sections. The cutoff levels for the probe sets were set at $11.0 \%$ (mean plus three times the standard deviation determined in seven negative control samples). ${ }^{20}$

\section{Allelic Imbalance as Detected by CGH-Array}

The genomic imbalances in mantle cell lymphoma detected by genome-wide array-based comparative genomic hybridization have been recently reported. ${ }^{23}$ The array-CGH data have been used in this study to examine whether certain chromosomal imbalances are correlated with mutation status or $\mathrm{V}_{\mathrm{H}}$ gene usage. In the array-CGH study, minimal common regions were defined as chromosomal regions that show copy number gain or loss in at least 5 of 14 patients. Moreover, for this study, we determined for each case the amount of BAC clones with copy number alterations (clones with a log2 ratio $>0.3$ or $<-0.3$ ). The number of clones with copy number alterations was divided by the amount of clones that gave a signal on the array, to calculate the percentage of clones with copy number alterations.

\section{Results}

\section{Histology, Immunohistochemistry and Translocation Detection}

The morphological and immunohistochemical features of our mantle cell lymphoma series are shown in Table 1. Four cases had monocytoid morphology of the tumor cells. In 21/23 cases, the growth pattern was (vaguely) nodular by histology. Remnants of germinal centers were seen in $2 / 23$ cases by histology and Ki-67 staining. In these two cases, a combination of mantle zone and nodular growth pattern was present. In the two cases with serial biopsies, there was no change in cellular morphology, growth pattern or immunohistochemistry features, even in the case with a 7-year interval between the first and the last biopsy (MC50, 51, $52,53)$. The great majority of cases $(19 / 23)$ were CD5 positive and all of the cases showed was stained by cyclinD1. For most cases, no additional cytogenetic data are available. Therefore, there are no additional data on the CD5-negative cases in relation to cytogenetics.

Breakpoints within the $B C L 1 / 11 \mathrm{q} 13$ locus were identified in all mantle cell lymphoma cases analyzed. The breakpoints were scattered in the $800-\mathrm{kb}$ region and mapped in different clusters (Table 2), 4 in the centromeric MTC-region (cluster 1), 6 in the 85-bp MTC-region, 13 between 
Table 2 Immunoglobulin, proliferation and survival data of mantle cell lymphoma

\begin{tabular}{|c|c|c|c|c|c|c|c|c|c|}
\hline \multirow[t]{2}{*}{ Sample } & \multirow[t]{2}{*}{$11 q 13 / B C L 1^{\mathrm{a}}$} & \multicolumn{4}{|c|}{$I G H$} & \multirow[t]{2}{*}{$I G K / I G L$} & \multirow[t]{2}{*}{ Ki-67 (\%) } & \multirow[t]{2}{*}{ Mitosis (15 hpf) } & \multirow[t]{2}{*}{ Survival (years) } \\
\hline & & $V$-gene & D-gene & J-gene & $\%$ of $S H$ & & & & \\
\hline MC07 & 4 & V4-b & D1-26 & $\mathrm{J} 4$ & 0.00 & $\mathrm{~V}_{\mathrm{K}} 4-1$ & 19.63 & 6 & $>5^{\mathrm{b}}$ \\
\hline MC43 & 2 & V3-7 & D5-5 & J3 & 0.00 & $\mathrm{~V}_{\mathrm{K}} 4-1$ & 26.44 & 4 & 4 \\
\hline MC44 & 3 & V3-21 & D3-22 & J6 & 0.00 & $\mathrm{~V}_{\lambda} 1-47^{\mathrm{c}}, \mathrm{V} 3$ & 19.85 & 2 & 1.5 \\
\hline MC58 & 1 & V3-53 & D3-22 & J5 & 0.00 & & 57.93 & 51 & 2 \\
\hline MC59 & 3 & V3-21 & D6-19 & J3 & 0.00 & & 20.03 & 1 & 8 \\
\hline MC62 & 3 & V3-7 & D3-22 & $\mathrm{J} 4$ & 0.00 & & 17.66 & 3 & \\
\hline MC42 & 2 & V2-26 & D3-3 & J4 & 0.39 & $\mathrm{~V}_{\mathrm{K}} 5$ & 17.76 & 12 & 1.5 \\
\hline MC17 & 3 & V3-21 & $\mathrm{D} 2-8$ & J6 & 0.43 & $\mathrm{~V}_{\lambda} 3-19$ & 19.28 & 17 & $>6^{\mathrm{b}}$ \\
\hline MC31 & 3 & V3-21 & D2-2 & J3 & 0.43 & $\mathrm{~V}_{\lambda} 3-19$ & 16.86 & 10 & 9 \\
\hline MC01 & $2+4$ & V4-34 & D3-10 & J3 & 0.44 & $V_{\lambda} 3, V_{\lambda} 1-47^{c}$ & 13.12 & 13 & \\
\hline MC47 & 3 & V4-39 & D6-13 & J5 & 0.44 & $\mathrm{~V}_{\lambda} 8-61$ & 11.92 & 6 & \\
\hline MC56 & 3 & V4-34 & D2-15 & J6 & 0.44 & $\mathrm{~V}_{\mathrm{K}} 2-30^{\mathrm{c}}$ & 26.79 & 0 & 3 \\
\hline MC57 & 3 & V3-21 & D6-13 & J6 & 1.30 & $V_{K}, 4-1^{c}, V_{K} 5-2^{c}$ & 16.96 & 3 & 0.25 \\
\hline $\mathrm{MC50}^{\mathrm{d}}$ & 2 & V4-34 & D5-5 & J4 & 1.33 & $\mathrm{~V}_{\lambda,} 3-21 \mathrm{~V}_{\lambda} 2-18$ & 14.94 & 0 & $>8^{\mathrm{b}}$ \\
\hline $\mathrm{MC5}^{\mathrm{d}}$ & ND & V4-34 & D5-5 & $\mathrm{J} 4$ & 1.33 & & 21.42 & 9 & $>8^{\mathrm{b}}$ \\
\hline $\mathrm{MC}^{2} 2^{\mathrm{d}}$ & ND & V4-34 & D5-5 & $\mathrm{J} 4$ & 1.33 & & 17.67 & 27 & $>8^{\mathrm{b}}$ \\
\hline $\mathrm{MC53}^{\mathrm{d}}$ & ND & V4-34 & D5-5 & J4 & 1.33 & & 29.23 & 9 & $>8^{\mathrm{b}}$ \\
\hline MC48 & 3 & V3-49 & D5-5 & J4 & 1.69 & $\mathrm{~V}_{\mathrm{K}} 1 / \mathrm{OR} 2-0^{\mathrm{c}}$ & 18.8 & 2 & NA \\
\hline MC67 & 2 & V3-7 & D1-1 & $\mathrm{J} 4$ & 1.74 & & 8.72 & 4 & 0.08 \\
\hline MC36 & 3 & V4-34 & D3-22 & J4 & 1.76 & & 56.84 & 20 & 1 \\
\hline $\mathrm{MC63}^{\mathrm{e}}$ & 3 & V3-33 & D2-15 & J4 & 2.16 & & & & $>4^{\mathrm{b}}$ \\
\hline MC66 $^{\mathrm{e}}$ & ND & V3-33 & D2-15 & J4 & 2.16 & & 15.27 & 7 & $>4^{\mathrm{b}}$ \\
\hline \multirow[t]{2}{*}{ MC45 } & 2 & V3-21 & D6-6 & J6 & 2.6 & & 39 & 4 & 1.5 \\
\hline & & $\mathrm{V} 2-5^{\mathrm{c}}$ & D6-6 & J4 & 1.19 & & & & \\
\hline MC29 & $1+4$ & V3-53 & D3-3 & J4 & 2.64 & $V_{\lambda} 1-40 \quad V_{\lambda} 2-11$ & 61.27 & 12 & \\
\hline MC08 & 1 & V1-18 & D6-6 & J5 & 3.57 & & 16.18 & 7 & 2.5 \\
\hline \multirow[t]{2}{*}{ MC65 } & 1 & V3-33 & D4-23 & J5 & 3.91 & & 19.99 & 5 & 1.5 \\
\hline & & $V 3-33^{\mathrm{c}}$ & D1-1 & J5 & 3.91 & & & & \\
\hline \multirow[t]{4}{*}{ MC61 } & 3 & V4-34 & D4-23 & J6 & 2.64 & & 8.29 & 1 & \\
\hline & & & & & 3.10 & & & & \\
\hline & & & & & 4.50 & & & & \\
\hline & & $\mathrm{V} 4-39^{\mathrm{c}}$ & D2-2 & J5 & 1.71 & & & & \\
\hline
\end{tabular}

a 1-4 represent the clusters in the 11q13/BCL1 locus, the centromeric MTC-region (1), the 85-bp MTC-region (2), between MTC and CCND1 (3) and telomeric of CCND1 (4).

${ }^{\mathrm{b}}$ Still alive.

${ }^{\mathrm{e}}$ Same patient.

${ }^{\mathrm{C}}$ These sequences are not in frame.

${ }^{\mathrm{d}}$ Same patient.

$\mathrm{hpf}=$ high power field; $\mathrm{ND}=$ not done.

For several of the cases, the IGL or IGK were sequenced.

MTC and CCND1 and 3 telomeric of CCND1. In 2 of the 23 cases, a double breakpoint was identified (MC01 and MC29). The mantle cell lymphoma cases all show variable proliferative activity (ki-67-staining) ranging from 8.29 to $61.27 \%$ and variable numbers of mitotic figures as shown in Table 2.

\section{Sequence Analysis and Mutation Frequencies of $V_{H}$ Genes}

From 23 patients, 26 unique $I G H$ gene rearrangements were amplified. Usage of the $\mathrm{V}_{\mathrm{H}}$-gene family was clearly unbalanced with preferential usage of $\mathrm{V}_{\mathrm{H}} 3$ and $\mathrm{V}_{\mathrm{H}} 4$ families accounting for 60 and $32 \%$ of all rearrangements, respectively. The most frequently used $\mathrm{V}_{\mathrm{H}}$ genes were $\mathrm{V}_{\mathrm{H}} 3-21 \quad(23 \%)$ and $\mathrm{V}_{\mathrm{H}} 4-34(19 \%)$. There was no usage of family $\mathrm{V}_{\mathrm{H}} 5$ and
$\mathrm{V}_{\mathrm{H}} 6$. Mutations in the $\mathrm{V}_{\mathrm{H}}$ gene segment were absent in six $\mathrm{V}_{\mathrm{H}}$ gene sequences, and another six sequences carried $<0.5 \%$ mutation frequencies; in 11 patients, mutated $I G H \mathrm{~V}_{\mathrm{H}}$ sequences were found in 6 of these to be more than $2 \%$ (Table 2).

From two patients, serial biopsies were available: cases 63 and 66 from one patient harbored identical mutations with a mutation frequency of $2.2 \%$. The serial biopsies from another patient (cases 50, 51, 52 and 53) also showed identical mutations (mutation load was $1.3 \%$ ).

The multiplex FR1 PCR (BIOMED-2) analysis showed that in three patients (MC45, MC65 and MC61) more than one IGH gene rearrangement was amplified (Figure 1). Case MC45 contained a $\mathrm{V}_{\mathrm{H}} 2-5$ rearrangement, which had a mutation load of $1.2 \%$ and was out of frame. The second was a VH3-21 rearrangement, which was in frame and had a 

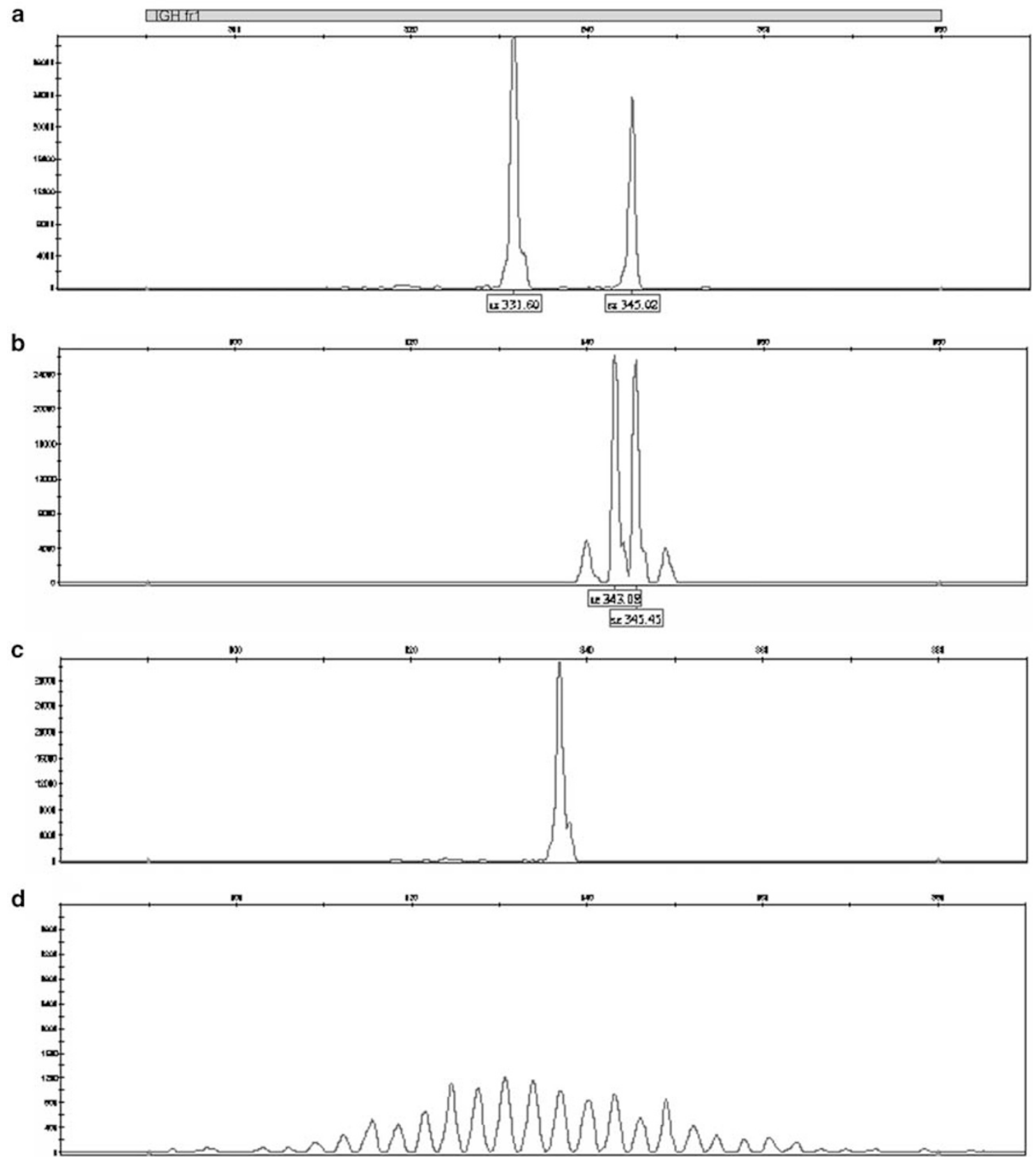

Figure 1 Genescan plots of MC45 (a), MC61 (b), a monoclonal control (c) and a polyclonal control (d). PCR was performed with BIOMED-2 multiplex IGH-VJ-FR1 forward primers and a JH consensus reverse primer. In both cases, multiple peaks were seen with the Genescan analysis.

mutation load of $2.6 \%$. In MC65, two V3-33 rearrangements were identified; both showed a $3.91 \%$ mutation load, but different D-gene usage. MC61 showed multiple PCR products, all of the $\mathrm{V}_{\mathrm{H}} 4$-family. To separate these products for sequence analysis, the mixture of PCR products was cloned into a PGEM-T vector. $A \mathrm{~V}_{\mathrm{H}}$ 4-39 rearrangement with a mutation load of $1.71 \%$ that was an out-of-frame rearrangement was identified. Also an in-frame $\mathrm{V}_{\mathrm{H}}$ 434 rearrangement was identified; more specifically, VH4-34D4-23J6 in 4 of 8 PGEM-T clones, showing three different patterns of somatic hypermutation as reported in Figure 2 and Table 2. The different mutation frequencies, in this particular case, might indicate ongoing somatic hypermutation.

\section{Rearrangement and Sequencing of Kappa and Lambda Chains}

IF data of the immunoglobulin light chains were available in 21 mantle cell lymphoma patients; of these, full analysis of kappa and lambda gene rearrangements by Southern blot was possible in 


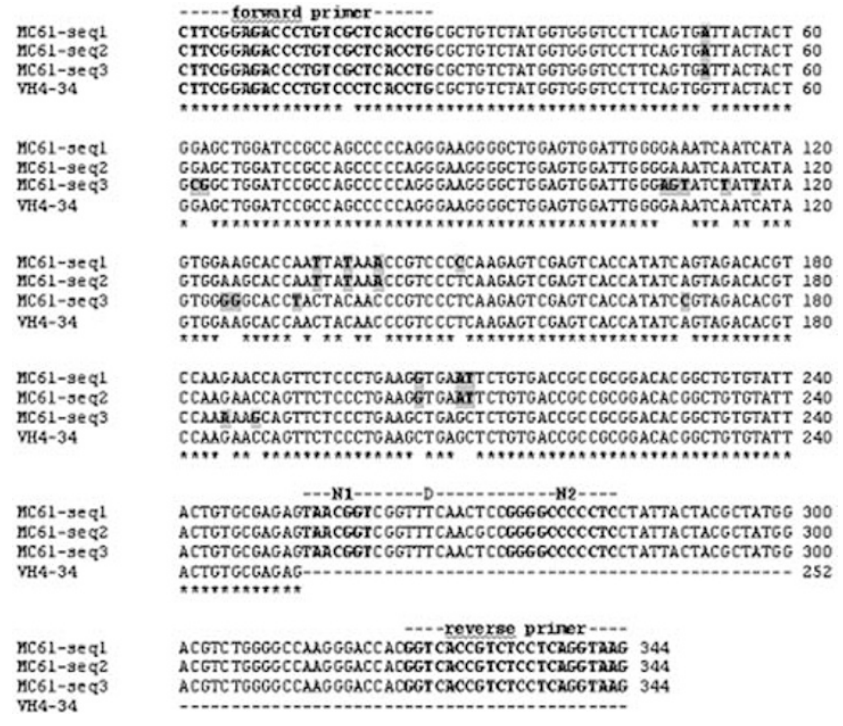

Figure 2 Nucleotide sequences of the three different $V_{H} 4-34$ clones found upon cloning of the FR1 amplicon of MC61. Differences in the nucleotide sequences are marked in gray. Percentage of somatic hypermutation: seq1, 3.11\%; seq2, $2.67 \%$; and seq3, $4.50 \%$.

19 patients. In 2 additional patients, due to a limited amount of DNA, only the Lambda gene was analyzed, resulting in SB analysis of 7 kappapositive and 13 lambda-positive cases (Table 3). When a complete in-frame $\mathrm{V}_{\mathrm{H}}-\mathrm{D}_{\mathrm{H}}-\mathrm{J}_{\mathrm{H}}$ heavy-chain rearrangement has been formed, rearrangement of the light-chain genes occurs. The Ig light-chain rearrangement process starts at the IGK locus. If no functional IGK gene rearrangements are formed, the cell can escape apoptosis by deleting the $\mathrm{J} \kappa-\mathrm{C} \kappa$ region, followed by $\mathrm{K}_{\mathrm{DE}}$ rearrangements and recombination at the IGL locus. ${ }^{24,25}$ IGK gene rearrangements were assessed by Southern blot. Most lambdaexpressing mantle cell lymphoma showed rearrangement of $K_{\mathrm{DE}}$ on both alleles (8 of 11). There was an overrepresentation of biallelic rearrangement of the lambda genes in unmutated cases (5 of 9), whereas mutated lambda-expressing cases retained one germline lambda gene in the majority of cases (3 of 4 ).

Sequence analysis of either the lambda or kappa genes was performed in 13 patients (Table 2). $V_{k} 4-1$ genes were used in three of the eight sequenced kappa genes. All three of the sequences of V kappagenes in lambda-expressing mantle cell lymphoma were out of frame. $V_{\lambda} 3-19$ genes were used in two of nine sequenced lambda genes; in both cases, this was associated with $\mathrm{V}_{\mathrm{H}} 3-21$ usage.

\section{Correlation of Chromosomal Imbalances with Mutation Frequencies and $V_{H}$ Gene Usage}

Chromosomal imbalances that occur in mantle cell lymphoma were identified previously with array-based genome-wide comparative genomic hybridization. ${ }^{23}$ In the array-CGH study, minimal common regions were identified, which are chromosomal regions that show copy number gain or loss in at least 5 of 14 patients. The total amount of minimal common regions varies between the cases with a minimum of 6 and a maximum of 13 minimal common regions. The mean amount of minimal common regions in cases with mutated $\mathrm{V}$ genes (11) did not differ from the mean of the cases with unmutated $\mathrm{V}$ genes $(9.5)(P=0.41)$.

Cases with $\mathrm{V}_{\mathrm{H}}$ 3-21 gene usage were reported to have less chromosomal alterations than cases with other V-gene usage. ${ }^{26}$ In our series, we also found that $\mathrm{V}_{\mathrm{H}} 3-21^{+}$cases showed a lower amount of minimal common regions(8.8) compared with $\mathrm{V}_{\mathrm{H}} 3-21^{-}$cases (10.1), but the difference is not significant $(P=0.36)$, which is probably because of the low number of cases. Also, the total number of clones with copy number changes did not differ $(P=0.65)$ between mutated (mean of $17.3 \%$ of the clones showed gain or loss) and unmutated cases $(15.2 \%)$. The same was found between cases with $\mathrm{V}_{\mathrm{H}} 3-21$ and other V-genes. Cases with $\mathrm{V}_{\mathrm{H}} 3-21$ had a mean of $12.1 \%$ of the clones with copy number changes, whereas cases with other V-genes had a mean of $17.1 \%$ clones $(P=0.142)$.

\section{Correlation of Mutational Status with Morphological, Clinical and Molecular Data}

No difference between mutated and unmutated mantle cell lymphoma on morphological grounds

Our series of mantle cell lymphomas represent a homogenous group on the basis of morphological and immunophenotypic characteristics (Table 1); however, there were $57 \%$ unmutated and $43 \%$ mutated cases. This finding indicates that mutational status is not displayed morphologically.

\section{No correlation of mutation frequency and survival years}

Localization of the tumor biopsy, gender and age of the patient are given in Table 1. From 18 patients, clinical data about the survival years were available (Table 2). Four patients were alive when the followup ended; they were surviving at least 4 years after the diagnosis of mantle cell lymphoma was made. The median survival of the deceased patients was 2.7 years. No correlation was found between mutation frequency of the mantle cell lymphoma and survival years of the patients. Furthermore, no relationship between mitotic rate and survival and between mitotic rate and mutational status was detectable.

No correlation between $V$ gene usage or molecular characteristics and survival

A preferential usage of $\mathrm{V}_{\mathrm{H}}$ genes was seen in mantle cell lymphoma; however no correlations were found between $V_{H}$ gene usage and survival. Also no 
Table 3 Southern blot analysis of the immunoglobulin light chains in mantle cell lymphoma

\begin{tabular}{|c|c|c|c|c|c|c|c|c|c|c|c|c|}
\hline & \multicolumn{6}{|c|}{ IgK expressing $(\mathrm{n}=7)$} & \multicolumn{6}{|c|}{ IgL expressing $(\mathrm{n}=13)$} \\
\hline & \multicolumn{3}{|c|}{ Kappa genes } & \multicolumn{3}{|c|}{ Lambda genes } & \multicolumn{3}{|c|}{ Kappa genes } & \multicolumn{3}{|c|}{ Lambda genes } \\
\hline & $G / G$ & $\begin{array}{c}G / R \\
G / K_{D E}\end{array}$ & $\begin{array}{c}R / R \\
R / K_{D E} \\
K_{D E} \\
/ K_{D E}\end{array}$ & $\mathrm{G} / \mathrm{G}$ & $G / R$ & $R / R$ & $G / G$ & $\begin{array}{c}G / R \\
G / K_{D E}\end{array}$ & $\begin{array}{c}R / R \\
R / K_{D E} \\
K_{D E} \\
/ K_{D E}\end{array}$ & $\mathrm{G} / \mathrm{G}$ & $G / R$ & $R / R$ \\
\hline Unmutated $(n=15)^{\mathrm{a}}$ & 0 & 4 & 2 & 2 & 4 & 0 & 0 & 1 & 6 & 0 & 4 & 5 \\
\hline Mutated $(n=5)$ & 0 & 1 & 0 & 0 & 1 & 0 & 0 & 1 & 3 & 0 & 3 & 1 \\
\hline
\end{tabular}

$\mathrm{G}$, germline; R, VJ-rearrangement, $\mathrm{K}_{\mathrm{DE}}$; rearrangements of $\mathrm{K}_{\mathrm{DE}}$.

${ }^{\mathrm{a}}$ In two lambda expression mantle cell lymphoma, only lambda genes were analyzed.

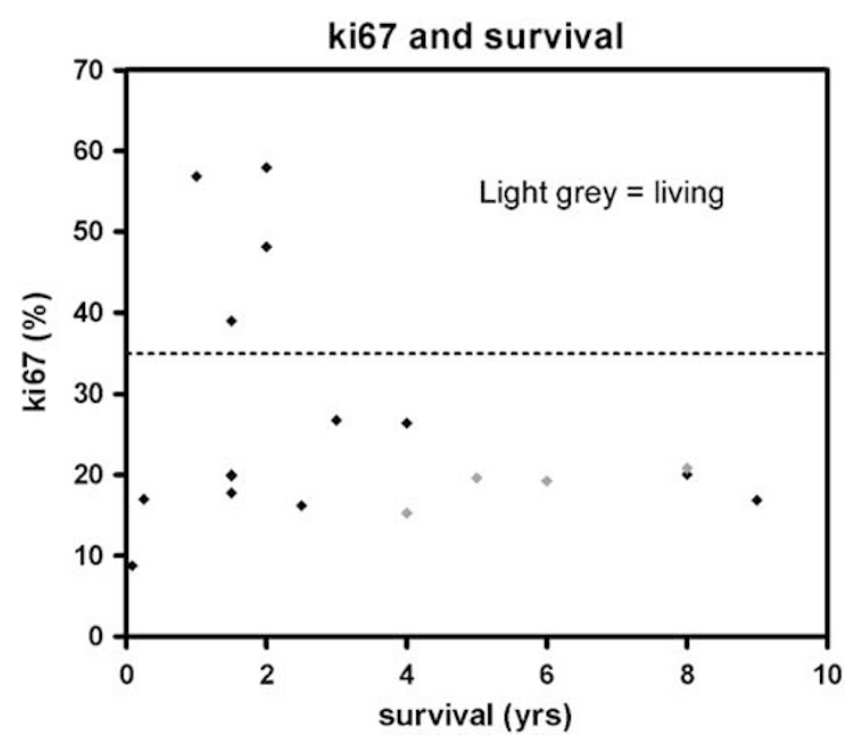

Figure 3 In our series, there is a statistically significant difference $(P=0.015)$ in survival time between mantle cell lymphoma with Ki-67-positive cells $\geq 35 \%$ and mantle cell lymphoma with Ki-67positive cells $<35 \%$, with a shorter median survival of 1.6 years in the first group compared with a median survival of 3.1 years in deceased patients of the second group.

correlations were found between chromosomal aberrations and survival. Finally, also no correlations were found between the positions of the breakpoints involved in the $\mathrm{t}(11 ; 14)$, such as in the telomeric MTC-region, the 85-bp MTC-region, between MTC and CCND1 or telomeric of CCND1 and survival.

High proliferation activity (Ki-67 staining) is an adverse prognostic factor

In our series, there is a statistically significant difference $(P=0,015)$ in survival time between mantle cell lymphoma with Ki-67-positive cells $\geq 35 \%$ and mantle cell lymphoma with Ki-67positive cells $<35 \%$ with a shorter median survival of 1.6 years in the first group compared with a median survival of 3.1 years in deceased patients of the second group (Figure 3). Moreover, in the latter group, there are four additional patients still living at least 4 years after diagnosis of mantle cell lymphoma was made (Welch two sample $t$-test, $t=2.7366, \mathrm{df}=14.955, P$-value $=0.01533$ ). No correlation of mutation frequency with Ki-67 level was detectable.

\section{Discussion}

Morphologically and immunophenotypically, neoplastic populations in mantle cell lymphoma resemble CD5 + B cells derived from the mantle zone of a lymphoid follicle. The CD5 + B cells of the mantle zone are naive lymphocytes that have not entered the germinal center of a secondary lymphoid follicle. Therefore, they lack somatic hypermutation of their $\mathrm{V}_{\mathrm{H}}$ genes. ${ }^{27}$ For long, it has been assumed that mantle cell lymphomas harbor unmutated $\mathrm{V}_{\mathrm{H}}$ genes, but more recently the origin of mantle cell lymphoma from the pregerminal center cells of the mantle zone has been questioned due to investigations reporting on mutation of $\mathrm{V}_{\mathrm{H}}$ genes in a considerable percentage of mantle cell lymphomas. ${ }^{8-12,27-29}$

In this study, we analyzed the mutational status of mantle cell lymphoma in 24 patients including serial biopsies taken from two patients. Both on morphological grounds and on the basis of results of immunohistochemistry, our cases of mantle cell lymphoma represent a very homogenous group, all cases being of the common type, all having the $\mathrm{t}(11 ; 14)(\mathrm{q} 13 ; 32)$ translocation and almost always CD5 positive. In our series, $26 \%$ of mantle cell lymphomas carried mutations of $\mathrm{V}_{\mathrm{H}}$ genes with a mutation load ranging from 2.16 to $4.44 \%$. In two cases from our series in which sequential biopsies were available for study, tumor cells displayed identical morphology and immunophenotype, that is, CD5- and cyclinD1-positivity, and similar proliferation activities. Both cases harbored mutations in the $\mathrm{V}_{\mathrm{H}}$ genes $(2.16 \%$ mutation frequency and $1.33 \%$ mutation frequency, respectively), but no change of mutation status over time was seen. 
One case showed biallelic rearrangement of the IGH locus, a $\mathrm{V}_{\mathrm{H}} 2-5$ and a $\mathrm{V}_{\mathrm{H}} 3-21$ gene rearrangement, which had a mutation status of 1.19 and $2.60 \%$, respectively. The $\mathrm{V}_{\mathrm{H}} 2-5$ gene rearrangement was not in frame and therefore this is not a functional rearrangement. Multiple clonal IGH rearrangements were shown in another case. Interestingly, upon cloning the multiplex PCR products, multiple clones showed an identical VDJ usage, but different patterns of somatic hypermutation, which might indicate the presence of ongoing somatic hypermutation. As this is a feature of germinal center B cells, it is in contrast with the idea that mantle cell lymphomas arise from pregerminal center cells. Also, a subset of mantle cell lymphomas are CD5-, which is also in contrast to the idea that these lymphomas arise from $\mathrm{CD} 5+$ naive $\mathrm{B}$ cells.

Although our series is small, we observed preferential usage of $\mathrm{V}_{\mathrm{H}} 3-21(23 \%)$ and $\mathrm{V}_{\mathrm{H}} 4-34(19 \%)$ in tumor cells of both mutated and unmutated cases. This is in keeping with the results of other authors, who reported an overrepresentation of these two $\mathrm{V}_{\mathrm{H}}$ gene segment usage in mantle cell lymphoma. ${ }^{9,11,12}$ $\mathrm{V}_{\mathrm{H}}$ 3-21 and $\mathrm{V}_{\mathrm{H}} 4-34$ both have been observed to be associated with autoimmune diseases, and the preferential usage of $\mathrm{V}_{\mathrm{H}}$ genes in lymphomas may indicate that antigens are involved in the development of those tumors. ${ }^{30-32}$ In our study, the five $V_{H}$ genes used most frequently $\left(\mathrm{V}_{\mathrm{H}} 3-21, \mathrm{~V}_{\mathrm{H}} 4-34, \mathrm{~V}_{\mathrm{H}} 3-33\right.$, $\left.\mathrm{V}_{\mathrm{H}} 3-7, \mathrm{~V}_{\mathrm{H}} 3-53\right)$ showed a balanced distribution in mutated and unmutated cases. Therefore, a possible antigen-dependent process with selection of $\mathrm{V}_{\mathrm{H}}$ genes probably has no influence on the mutation status of the $\mathrm{V}_{\mathrm{H}}$ genes.

The same seems to apply to selection of the immunoglobulin light-chain genes. Mutated and unmutated mantle cell lymphomas did not show any difference in the preferential use of Vkappa 4-1, Vlambda1-47 and Vlambda 3-1. Vkappa 4-1 is located closest of all $\mathrm{V}$ gene segments to the J genes (downstream) and is rarely used in peripheral B cells. $^{33}$ Increased usage of downstream Vkappa segments, including Vkappa $4-1$, is reported in rheumatoid arthritis. ${ }^{34}$ The predominant Vlambda genes are located more upstream from the J genes and are commonly used in peripheral B cells, as well as in B-chronic lymphocytic leukemia, indicating that they usually have proceeded through several receptor rearrangements. ${ }^{33,35}$ We identified a slightly higher total number of rearranged genes in unmutated mantle cell lymphoma, resulting from more lambda rearrangements. The lambda rearrangements consisted both of biallelic lambda rearrangements in lambda-expressing cases, as well as 'illegal' lambda rearrangements in kappa-expressing cases. ${ }^{25}$ Although 'illegal' lambda gene rearrangements occur in naive kappa-expressing B cells, their frequency $(1.5 \%)$ is much lower than the $19 \%$ we observed in mantle cell lymphoma. ${ }^{36}$ The mantle cell lymphoma light-chain rearrangement patterns also were very similar to those in mutated and unmutated B-chronic lymphocytic leukemia, which supports the idea that somatic mutation does not influence the light-chain recombination. ${ }^{35}$

Recently, Flordal Thelander et $a l^{26}$ reported that mantle cell lymphomas with clonal $\mathrm{V}_{\mathrm{H}} 3-21$ rearrangements exhibit fewer genomic imbalances than mantle cell lymphomas with other rearrangements. In our series, no statistical significant relationship could be established between $\mathrm{V}_{\mathrm{H}}$ rearrangements and the occurrence of genomic imbalances. Flordal Thelander et $a 1^{26}$ made use of classic CGH, which has a limited resolution, and they might have missed small imbalances that could be detected with the array-CGH used to analyze our cases. Also no specific genomic alterations could be correlated with the presence or absence of hypermutation.

In chronic lymphocytic leukemia (chronic lymphocytic leukemia), it has been shown that cases with mutated $I G V_{H}$ sequences have a better prognosis than unmutated cases. ${ }^{14,15}$ Moreover, patients with $\mathrm{V}_{\mathrm{H}} 3-21$ usage, independent of mutation status, have a poor outcome compared with cases with other $\mathrm{VH}$ usage. ${ }^{14,15}$ In contrast, mantle cell lymphoma cases with $\mathrm{V}_{\mathrm{H}} 3-21$ rearrangements seem to have a tendency toward a better prognosis as was shown by others. ${ }^{8,9}$ In chronic lymphocytic leukemia patients, the $\mathrm{V}_{\mathrm{H}} 3-21^{+}$patients show a biased usage of $V_{2} 2-14 .^{14,15}$ In this study, sequence analysis of the kappa or lambda rearrangements was performed in three of the six cases with $\mathrm{V}_{\mathrm{H}} 3-21$ usage. $\mathrm{V}_{\lambda}$ 3-19 usage was seen in two cases and $\mathrm{V}_{\lambda}$ 2-14 usage was seen in the third case.

In line with other investigators, we did not identify a correlation of mutational status and survival time in our series. ${ }^{8,9,12,37}$ In mantle cell lymphoma patients with $\mathrm{V}_{\mathrm{H}}$-mutations, we did not see a favorable prognosis independent of the cutoff level of mutations. This was also confirmed by a study undertaken by Walsh et $a l,{ }^{12}$ who correlated survival of patients with different cutoff percentages ranging from 1 to $5 \%$. No significant differences in median survival times were found when comparing mutated and unmutated mantle cell lymphoma. One of the adverse prognostic parameters reported most consistently in mantle cell lymphoma is the proliferative activity of the tumor, represented histopathologically by a high number of mitoses and immunohistochemically by the level of $\mathrm{Ki}-67$, a marker of cell proliferation. However, controversy continues about the number of mitotic figures and the level of expression of Ki-67 requisite to indicate a poor prognosis. ${ }^{3,6,7,38}$ In our study, there was a statistically significant difference between mantle cell lymphoma with a Ki-67-positivity $<35 \%$ and mantle cell lymphoma with a Ki-67-positivity $\geq 35 \%$ in regard to a longer survival time in the former, whereas mutation status of both groups did not correlate with Ki-67-positivity.

In conclusion, our results provide additional evidence that mutation status does not permit 
definition of subentities in mantle cell lymphoma that are associated invariably with a certain prognosis. Mutation status in mantle cell lymphoma is better interpreted as a feature within the spectrum of disease that seems to have little clinical or pathological relevance.

\section{Acknowledgement}

We are grateful to the excellent practical assistance of Rinny de Boer-Bergsma and Karine Akkermans.

\section{Conflict of interest}

The authors have no conflicts of interest to disclose.

\section{References}

1 Meusers P, Hense J, Brittinger G. Mantle cell lymphoma: diagnostic criteria, clinical aspects and therapeutic problems. Leukemia 1997;11(Suppl 2):S60-S64.

2 Weisenburger DD, Armitage JO. Mantle cell lymphoma-an entity comes of age. Blood 1996;87:4483-4494.

3 Raty R, Franssila K, Joensuu H, et al. Ki-67 expression level, histological subtype, and the International Prognostic Index as outcome predictors in mantle cell lymphoma. Eur J Haematol 2002;69:11-20.

4 Pinyol M, Hernandez L, Cazorla M, et al. Deletions and loss of expression of p16INK4a and p21Waf1 genes are associated with aggressive variants of mantle cell lymphomas. Blood 1997;89:272-280.

5 Allen JE, Hough RE, Goepel JR, et al. Identification of novel regions of amplification and deletion within mantle cell lymphoma DNA by comparative genomic hybridization. Br J Haematol 2002;116:291-298.

6 Greiner TC, Moynihan MJ, Chan WC, et al. p53 mutations in mantle cell lymphoma are associated with variant cytology and predict a poor prognosis. Blood 1996;87:4302-4310.

7 Louie DC, Offit K, Jaslow R, et al. p53 overexpression as a marker of poor prognosis in mantle cell lymphomas with $\mathrm{t}(11 ; 14)(\mathrm{q} 13 ; \mathrm{q} 32)$. Blood 1995;86:2892-2899.

8 Camacho FI, Algara P, Rodriguez A, et al. Molecular heterogeneity in mantle cell lymphoma defined by the use of specific $\mathrm{VH}$ genes and the frequency of somatic mutations. Blood 2003;101:4042-4046.

9 Kienle D, Krober A, Katzenberger T, et al. VH mutation status and VDJ rearrangement structure in mantle cell lymphoma: correlation with genomic aberrations, clinical characteristics, and outcome. Blood 2003;102:3003-3009.

10 Orchard J, Garand R, Davis Z, et al. A subset of t(11;14) lymphoma with mantle cell features displays mutated IgVH genes and includes patients with good prognosis, nonnodal disease. Blood 2003;101:4975-4981.

11 Thorselius M, Walsh S, Eriksson I, et al. Somatic hypermutation and $\mathrm{V}(\mathrm{H})$ gene usage in mantle cell lymphoma. Eur J Haematol 2002;68:217-224.

12 Walsh SH, Thorselius M, Johnson A, et al. Mutated VH genes and preferential VH3-21 use define new subsets of mantle cell lymphoma. Blood 2003;101:4047-4054.
13 Damle RN, Wasil T, Fais F, et al. Ig V gene mutation status and CD38 expression as novel prognostic indicators in chronic lymphocytic leukemia. Blood 1999;94:1840-1847.

14 Hamblin TJ, Davis Z, Gardiner A, et al. Unmutated Ig $\mathrm{V}(\mathrm{H})$ genes are associated with a more aggressive form of chronic lymphocytic leukemia. Blood 1999;94:1848-1854.

15 Maloum K, Davi F, Merle-Beral H, et al. Expression of unmutated $\mathrm{VH}$ genes is a detrimental prognostic factor in chronic lymphocytic leukemia. Blood 2000;96: 377-379.

16 van der Avoort IA, van der Laak JA, Paffen A, et al. MIB1 expression in basal cell layer: a diagnostic tool to identify premalignancies of the vulva. Mod Pathol 2007;20:770-778.

17 Van Dongen JJ, Langerak AW, Bruggemann M, et al. Design and standardization of PCR primers and protocols for detection of clonal immunoglobulin and T-cell receptor gene recombinations in suspect lymphoproliferations: report of the BIOMED-2 concerted action BMH4-CT98-3936. Leukemia 2003;17:2257-2317.

18 Beishuizen A, Verhoeven MA, Mol EJ, et al. Detection of immunoglobulin kappa light-chain gene rearrangement patterns by Southern blot analysis. Leukemia 1994;8:2228-2236.

19 Tumkaya T, Beishuizen A, Wolvers-Tettero IL, et al. Identification of immunoglobulin lambda isotype gene rearrangements by Southern blot analysis. Leukemia 1996;10:1834-1839.

20 Haralambieva E, Kleiverda K, Mason DY, et al. Detection of three common translocation breakpoints in non-Hodgkin's lymphomas by fluorescence in situ hybridization on routine paraffin-embedded tissue sections. J Pathol 2002;198:163-170.

21 Specht K, Haralambieva E, Bink K, et al. Different mechanisms of cyclin D1 overexpression in multiple myeloma revealed by fluorescence in situ hybridization and quantitative analysis of mRNA levels. Blood 2004;104:1120-1126.

22 Janssen JW, Vaandrager JW, Heuser T, et al. Concurrent activation of a novel putative transforming gene, myeov, and cyclin D1 in a subset of multiple myeloma cell lines with $\mathrm{t}(11 ; 14)(\mathrm{q} 13 ; \mathrm{q} 32)$. Blood 2000;95: 2691-2698.

23 Schraders M, Pfundt R, Straatman HM, et al. Novel chromosomal imbalances in mantle cell lymphoma detected by genome-wide array-based comparative genomic hybridization. Blood 2005;105:1686-1693.

24 Siminovitch KA, Bakhshi A, Goldman P, et al. A uniform deleting element mediates the loss of kappa genes in human B cells. Nature 1985;316:260-262.

25 Van Dongen JJ, Adriaansen HJ. Immunobiology of leukemia. In: Henderson ES, Lister TA, Greaves MF (eds). Leukemia, 6th edn. WB Saunders: Philadelphia, 1996;83-130.

26 Flordal TE, Walsh SH, Thorselius M, et al. Mantle cell lymphomas with clonal immunoglobulin V(H)3-21 gene rearrangements exhibit fewer genomic imbalances than mantle cell lymphomas utilizing other immunoglobulin V(H) genes. Mod Pathol 2004;18: 331-339.

27 Kuppers R, Klein U, Hansmann ML, et al. Cellular origin of human B-cell lymphomas. N Engl J Med 1999;341:1520-1529.

28 Frater JL, Hsi ED. Properties of the mantle cell and mantle cell lymphoma. Curr Opin Hematol 2002;9:56-62. 
29 Hummel M, Tamaru J, Kalvelage B, et al. Mantle cell (previously centrocytic) lymphomas express VH genes with no or very little somatic mutations like the physiologic cells of the follicle mantle. Blood 1994;84:403-407.

30 Bhat NM, Bieber MM, Spellerberg MB, et al. Recognition of auto- and exoantigens by V4-34 gene encoded antibodies. Scand J Immunol 2000;51:134-140.

31 Elagib KE, Borretzen M, Jonsson R, et al. Rheumatoid factors in primary Sjogren's syndrome (pSS) use diverse $\mathrm{VH}$ region genes, the majority of which show no evidence of somatic hypermutation. Clin Exp Immunol 1999;117:388-394.

$32 \mathrm{He} \mathrm{X,} \mathrm{Goronzy} \mathrm{JJ,} \mathrm{Zhong} \mathrm{W,} \mathrm{et} \mathrm{al.} \mathrm{VH3-21} \mathrm{B} \mathrm{cells}$ escape from a state of tolerance in rheumatoid arthritis and secrete rheumatoid factor. Mol Med 1995;1:768-780.

33 Meffre E, Milili M, Blanco-Betancourt C, et al. Immunoglobulin heavy chain expression shapes the B cell receptor repertoire in human B cell development. J Clin Invest 2001;108:879-886.
34 Samuels J, Ng YS, Coupillaud C, et al. Human B cell tolerance and its failure in rheumatoid arthritis. Ann N Y Acad Sci 2005;1062:116-126.

35 van der BM, Barendregt $\mathrm{BH}$, van Wering ER, et al. The presence of somatic mutations in immunoglobulin genes of B cell acute lymphoblastic leukemia (ALL-L3) supports assignment as Burkitt's leukemia-lymphoma rather than B-lineage ALL. Leukemia 2001;15:1141-1143.

36 Brauninger A, Goossens T, Rajewsky K, et al. Regulation of immunoglobulin light chain gene rearrangements during early B cell development in the human. Eur J Immunol 2001;31:3631-3637.

37 Bertoni F, Conconi A, Cogliatti SB, et al. Immunoglobulin heavy chain genes somatic hypermutations and chromosome 11q22-23 deletion in classic mantle cell lymphoma: a study of the Swiss Group for Clinical Cancer Research. Br J Haematol 2004;124:289-298.

38 Martinez A, Bellosillo B, Bosch F, et al. Nuclear survivin expression in mantle cell lymphoma is associated with cell proliferation and survival. Am J Pathol 2004;164:501-510. 